\title{
Roseburia intestinalis sp. nov., a novel saccharolytic, butyrate-producing bacterium from human faeces
}

Gut Microbiology and Immunology Division, Rowett Research Institute, Bucksburn, Aberdeen AB21 9SB, UK

\author{
Sylvia H. Duncan, Georgina L. Hold, Adela Barcenilla, Colin S. Stewart \\ and Harry J. Flint
}

\begin{abstract}
Author for correspondence: Sylvia H. Duncan. Tel: +44 1224 712751. Fax: +44 1224716687. e-mail: shd@rri.sari.ac.uk

Five strains of butyrate-producing, anaerobic, Gram-positive bacteria were isolated from human faecal material. These strains were slightly curved rods that showed motility by means of multiple subterminal flagella. The DNA G + C content of the strains was $29-31 \mathrm{~mol} \%$. A detailed investigation of the phenotypic and phylogenetic characteristics of the strains revealed that they represent a novel species of anaerobic, low-G+C-content, butyrate-producing bacterium that shows net acetate utilization during growth on media containing carbohydrates and short-chain fatty acids. The 165 rRNA gene sequences of the five isolates were determined and they confirmed that these strains were closely related to each other. Phylogenetic analysis indicated that the most closely related species are Eubacterium rectale, Eubacterium oxidoreducens and Roseburia cecicola, members of cluster XIVa of the Clostridium subphylum of Gram-positive bacteria, although they share less than $95 \%$ sequence identity with the novel strains. It is proposed that a novel species, Roseburia intestinalis sp. nov., be created, with strain L1-82 ${ }^{\top}$ ( = DSM $14610^{\top}=N^{\prime}$ CIMB $13810^{\top}$ ) as the type strain.
\end{abstract}

Keywords: Roseburia intestinalis, human faeces, butyrate, low- $\mathrm{G}+\mathrm{C}$ bacteria, cluster XIVa

\section{INTRODUCTION}

Butyrate produced by fermentation in the human colon is considered to have health-promoting properties (von Engelhardt et al., 1998; Scheppach et al., 1995). There is, however, only limited information concerning bacterial strains capable of butyrate production in the human gut. Barcenilla et al. (2000) isolated butyrate-producing bacteria from human faeces and showed that the vast majority fell within the low-G $+\mathrm{C}$ cluster XIVa as defined by Collins et al. (1994). However, based on 16S rDNA sequence analysis, more than $50 \%$ of the strains examined were less than $95 \%$ related to known species. Barcenilla et al. (2000) also categorized the butyrate-producing strains based on their restriction profiles with the

Abbreviation: SCFA, short-chain fatty acids.

The GenBank accession numbers for the 16S rDNA sequences of the $R$. intestinalis strains are AJ270478-AJ270480, AJ312385 and AJ312386. enzyme $A l u \mathrm{I}$. One particular ribogroup considered here, ribogroup 1, which accounted for 13 of the 74 strains isolated, formed a distinct cluster related to Roseburia cecicola, Eubacterium oxidoreducens and Eubacterium rectale on the basis of phylogenetic analysis of $16 \mathrm{~S}$ rDNA sequences.

The genus Eubacterium was defined by Prévot to include isolates from human faeces that possessed properties beneficial to human health (reviewed by Prévot, 1966). Later, Moore \& Holdeman Moore (1986) described Eubacterium as a convenient but diverse taxon, based mainly on bacteria that could not be assigned to other genera. Eubacterium species have now been found in a range of other habitats including animal faeces (Moore et al., 1987; Mott \& Brinkley, 1979), the rumen (Bryant, 1959), the oral cavity (Holdeman et al., 1980) and infections (Sans \& Crowder, 1973). Certain species may be recovered from the soil or sewage (Moore \& Holdeman Moore, 1986). They are obligately anaerobic, Gram-positive, non-spore-forming rods. Many species use sugars, but 
the genus also includes non-saccharolytic species. Most species produce butyric acid and hydrogen gas. Many produce lactate, but neither propionate nor succinate is a major product (Bokkenheuser et al., 1979; Krumholz \& Bryant, 1986; reviewed by Andreesen, 1992). The species $R$. cecicola, reported from the mouse intestine (Stanton \& Savage, 1983a), shares many of these characteristics and is most closely related to E. rectale. Based on $16 \mathrm{~S}$ rDNA sequence analyses, most Eubacterium species and $R$. cecicola belong to the Clostridium coccoides cluster of low$\mathrm{G}+\mathrm{C}$-content Gram-positive bacteria (Willems et al., 1996). Interest in the role of these species in the human gut is increasing because of evidence that this cluster accounts for $40-50 \%$ of eubacterial sequences in studies of randomly cloned $16 \mathrm{~S}$ rDNA from human faeces (Suau et al., 1999; Franks et al., 1998).

Although the contribution of Eubacterium and its relatives to colonic metabolism has still to be elucidated, it is considered that these species may account for much of the butyrate produced in the human large intestine (Barcenilla et al., 2000). Butyrate is an important nutrient for colonocytes, as well as a signalling molecule with a central role in cell differentiation and apoptosis (von Engelhardt et al., 1998; Scheppach et al., 1995). Eubacterium species also contribute to other important processes within the human gut: for example, Eubacterium ramulus (Simmering et al., 1999) forms phenolic acids from a range of flavonoids including quercitin, rutin and luteolin (Schneider \& Blaut, 2000) and is likely to be one of the most important flavonoid-transforming bacteria in the gut (Schneider et al., 2000).

It is proposed that the isolates reported here should be placed in a novel species, named Roseburia intestinalis sp. nov. in view of its habitat and its relationship to $R$. cecicola, with strain $\mathrm{L} 1-82^{\mathrm{T}}$ as the type strain.

\section{METHODS}

Anaerobic methods and media. Five butyrate-producing strains (L1-82 ${ }^{\mathrm{T}}$, L1-952, L1-8151, L1-81 and L1-93) were isolated from the highest countable dilution of healthy infant faecal samples in roll tubes of anaerobic M2GSC medium (Miyazaki et al., 1997) as described by Barcenilla et al. (2000). Anaerobic culture methods were those of Bryant (1972) using Hungate culture tubes, sealed with butyl rubber septa (Bellco Glass Inc.). Media were prepared and maintained anaerobically using $\mathrm{O}_{2}$-free $\mathrm{CO}_{2}$. The isolates were routinely maintained by growing for $16-18 \mathrm{~h}$ at $37^{\circ} \mathrm{C}$ in $7 \cdot 5 \mathrm{ml}$ aliquots of M2GSC medium.

Morphology. The cellular morphology of the novel isolates was determined by Gram-staining exponential- and stationary-phase cultures as described by Holdeman et al. (1977). Motility was determined by examination of $16 \mathrm{~h}$ old cultures by phase-contrast microscopy. The presence of flagella was observed by scanning electron microscopy (SEM) following the procedure described by Stewart et al. (1990).

Substrate utilization and hydrolysis. Substrate utilization was determined by adding a final concentration of $0.5 \%$ of stock $(10 \%, \mathrm{w} / \mathrm{v})$ filter-sterilized sugar solutions to YCFA medium dispensed in $7.5 \mathrm{ml}$ amounts in Hungate tubes. The medium consisted of (in $100 \mathrm{ml}$ ) $1 \mathrm{~g}$ casitone, $0.25 \mathrm{~g}$ yeast extract, $0.4 \mathrm{~g} \mathrm{NaHCO}, 0.1 \mathrm{~g}$ cysteine, $0.045 \mathrm{~g} \mathrm{~K}_{2} \mathrm{HPO}_{4}$, $0.045 \mathrm{~g} \mathrm{KH}{ }_{2} \mathrm{PO}_{4}, 0.09 \mathrm{~g} \mathrm{NaCl}, 0.009 \mathrm{~g} \mathrm{MgSO}_{4} .7 \mathrm{H}_{2} \mathrm{O}$, $0.009 \mathrm{~g} \mathrm{CaCl}_{2}, 0 \cdot 1 \mathrm{mg}$ resazurin, $1 \mathrm{mg}$ haemin, $1 \mu \mathrm{g}$ biotin, $1 \mu \mathrm{g}$ cobalamin, $3 \mu \mathrm{g} p$-aminobenzoic acid, $5 \mu \mathrm{g}$ folic acid and $15 \mu \mathrm{g}$ pyridoxamine. Final concentrations of shortchain fatty acids (SCFA) in the medium were $33 \mathrm{mM}$ acetate, $9 \mathrm{mM}$ propionate and $1 \mathrm{mM}$ each of isobutyrate, isovalerate and valerate. All components were added aseptically while the tubes were flushed with $\mathrm{CO}_{2}$. Heat-labile vitamins were added after the medium was autoclaved to give a final concentration of $0.05 \mu \mathrm{g}$ thiamin $\mathrm{ml}^{-1}$ and $0.05 \mu \mathrm{g}$ riboflavin $\mathrm{ml}^{-1}$. YCFA supplemented with a carbon source provided a convenient alternative to rumen-fluid medium for the cultivation of the strains in this study. Growth was measured spectrophotometrically as $\mathrm{OD}_{650}$. Twelve different arylamidase activities were tested using the Rapid ID-32A system (bioMérieux). The compounds tested were arginine arylamide (A), proline $\mathrm{A}$, leucine glycine $\mathrm{A}$, phenylalanine A, leucine A, pyroglutamic acid A, tyrosine A, alanine A, glycine $\mathrm{A}$, histidine $\mathrm{A}$, serine $\mathrm{A}$ and glutamyl glutamic acid A. Aesculin hydrolysis was determined as described by Duncan et al. (1998).

Fermentation product analysis. Acid production was determined by capillary GC (Richardson et al., 1989) and the gaseous products were analysed by packed-column GC (Rumney et al., 1995).

DNA preparation and DNA base composition. DNA was extracted from $24 \mathrm{~h}$ old cultures grown on M2GSC medium following the method of Ausubel et al. (1994). Chromosomal DNA was purified by standard methods (Sambrook et al., 1989), with the $G+C$ content determined using the thermal denaturation procedure as described by Johnson (1981).

16S rDNA sequencing and phylogenetic analysis. For amplification of $16 \mathrm{~S}$ rDNA, a universal primer set was used that corresponded to positions 8-27 (forward primer) and 14921510 (reverse primer) of the Escherichia coli numbering system (Weisburg et al., 1991). The PCR operating conditions were as described by Wood et al. (1998). Direct sequencing of the amplified DNA fragments was performed using an automated ABI 377 sequencer as described previously (Hold et al., 2001). Similarity of the 16S rDNA sequences from the five strains to sequences of other organisms was compared with all sequence data in GenBank and EMBL using the BLAST algorithm (Gish \& States, 1993) and the Ribosomal Database Project (Maidak et al., 1994). Nucleotide sequences were aligned with reference 16S rDNA gene sequences and phylogenetic trees were constructed using the neighbour-joining method (Saitou \& Nei, 1987) via the PHYLIP package (Felsenstein, 1989) using DNADIST for distance analysis (Kimura, 1980).

\section{RESULTS}

\section{Cell morphology, fermentation products and response to SCFA}

The novel strains isolated from human faeces were Gram-variable-staining, slightly curved rods measuring approximately $0.5 \times 1.5-5.0 \mu \mathrm{m}$ (Table 1). Cells stained predominantly Gram-positive in young cultures $(8-10 \mathrm{~h})$. All five isolates were motile when examined by phase-contrast microscopy, with SEM of 
Table 1. Phenotypic properties of strains of Roseburia intestinalis sp. nov.

Cells of all strains are motile rods and stain Gram-variable. All strains are negative for arylamidase, fermentation of mannitol, melezitose, rhamnose, ribose, trehalose and chicory inulin and indole, urease and catalase. All strains are positive for fermentation of glucose, raffinose, sucrose, xylose, starch and oat-spelt xylan, hydrolysis of aesculin and gas production from carbon dioxide and hydrogen. NT, Not tested; w, weak.

\begin{tabular}{|c|c|c|c|c|c|}
\hline Property & $\mathbf{L 1}^{-82^{\mathrm{T}}}$ & L1-952 & L1-8151 & L1-81 & L1-93 \\
\hline Cell size $(\mu \mathrm{m})$ & $0 \cdot 5 \times 1 \cdot 5-3 \cdot 0$ & $0 \cdot 5 \times 2 \cdot 5-5 \cdot 0$ & $0.5 \times 3 \cdot 0-5 \cdot 0$ & $0.5 \times 3 \cdot 0-4.0$ & $0.5 \times 3.0-4.0$ \\
\hline Flagella & Multiple & Multiple & Multiple & NT & NT \\
\hline DNA G $+C$ content $(\mathrm{mol} \%)$ & 31 & 29 & 29 & NT & NT \\
\hline \multicolumn{6}{|l|}{ Fermentation of: } \\
\hline Arabinose & + & + & + & + & w \\
\hline Cellobiose & $\mathrm{w}$ & + & + & + & + \\
\hline Fructose & + & + & + & $\mathrm{W}$ & + \\
\hline Maltose & w & + & + & + & + \\
\hline Melibiose & w & + & w & w & W \\
\hline
\end{tabular}

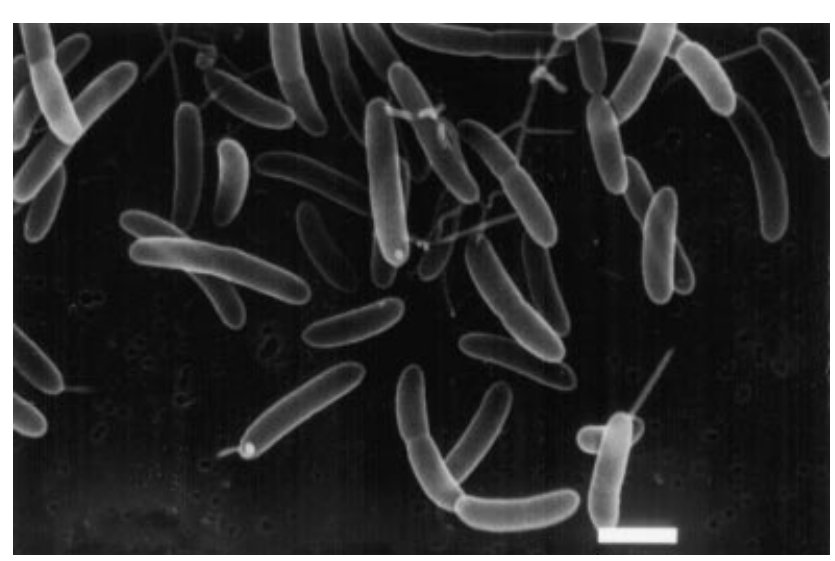

Fig. 1. Scanning electron micrograph of Roseburia intestinalis sp. nov. L1-82 ${ }^{\top}$ showing a flagella bundle. Bar, $1 \mu \mathrm{m}$.

Table 2. Fermentation products formed by strains of Roseburia intestinalis sp. nov.

Values are amounts of compounds produced/consumed $(-)$,

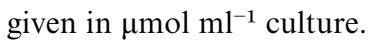

\begin{tabular}{|lrrrrr|}
\hline Compound & L1-82 $^{\mathbf{T}}$ & L1-952 & L1-8151 & L1-81 & L1-93 \\
\hline Formate & $4 \cdot 7$ & $5 \cdot 5$ & $3 \cdot 4$ & $4 \cdot 4$ & $1 \cdot 1$ \\
Acetate & $-9 \cdot 1$ & $-10 \cdot 1$ & $-12 \cdot 3$ & $-14 \cdot 2$ & $-10 \cdot 6$ \\
Butyrate & $18 \cdot 5$ & $21 \cdot 3$ & $16 \cdot 0$ & $21 \cdot 0$ & $10 \cdot 0$ \\
Lactate & $10 \cdot 2$ & $7 \cdot 1$ & $5 \cdot 5$ & $3 \cdot 6$ & $5 \cdot 7$ \\
\hline
\end{tabular}

strain L $1-82^{\mathrm{T}}$ demonstrating the presence of multiple flagella located subterminally (Fig. 1).

Analysis of fermentation products of cells grown in medium M2G showed that butyrate and L-lactate were the main products, with more than $10 \mu$ mol butyrate $\mathrm{ml}^{-1}$ produced in vitro. Formate was also detected, but only as a minor product (Table 2). Hydrogen and carbon dioxide were also formed. Acetate was not essential for growth but the addition of between 20 and $100 \mathrm{mM}$ acetate stimulated growth (maximum $\mathrm{OD}_{650}$ ) by approximately $20 \%$ and was utilized during growth on glucose (Duncan et al., 2002). Branched-chain SCFA (isobutyrate and isovalerate) did not stimulate growth (data not shown). All strains were net acetate utilizers, removing between 9 and $14 \mu \mathrm{mol}$ acetate $\mathrm{ml}^{-1}$ from the growth medium (Table 2).

\section{Substrates fermented and hydrolysed}

Aesculin was hydrolysed and weak fermentation of melibiose was detected. The substrates arabinose, cellobiose, fructose, maltose, raffinose, sucrose, xylose and starch were all fermented. Rhamnose, melezitose, mannitol, ribose, inulin and trehalose were not fermented, and arylamidase activity was not detected using the Rapid ID-32A system.

\section{Molecular characterization and phylogenetic relationships}

Incomplete $16 \mathrm{~S}$ rDNA sequences of three ribotype 1 strains (L1-81, L1-952 and L1-93) were reported previously and shown to cluster together during phylogenetic analysis (Barcenilla et al., 2000). Here, the $16 \mathrm{~S}$ rDNA sequences of these three strains were completed and sequences were also determined for two further strains, L1-82 $2^{\mathrm{T}}$ and L1-8151. The five strains show more than $98.5 \%$ sequence similarity to each other, but share $<95 \%$ sequence identity with the most closely related species, $E$. rectale, $E$. oxidoreducens and $R$. cecicola (Fig. 2). The DNA G+C content determined for three of the strains was between 29 and $31 \mathrm{~mol} \%$ (Table 1 ). 


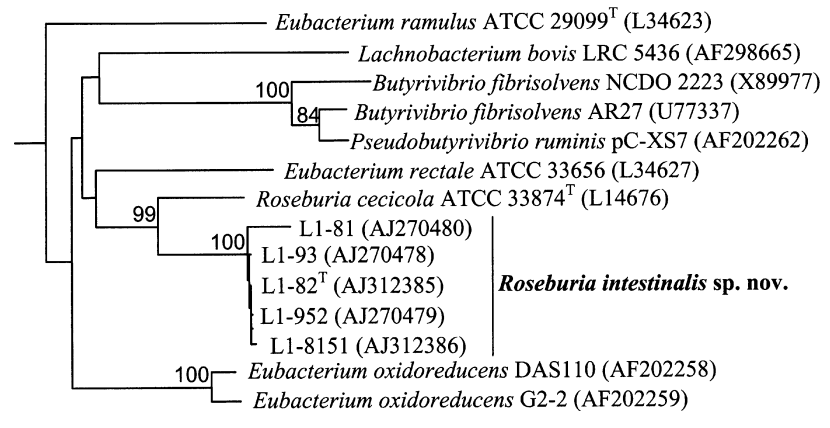

Fig. 2. Phylogenetic tree, constructed by the neighbour-joining method, based on $16 \mathrm{~S}$ rDNA sequences of the novel isolates L1$82^{\top}, \mathrm{L} 1-952, \mathrm{~L} 1-8151, \mathrm{~L} 1-81$ and $\mathrm{L} 1-93$ and related bacteria. Sequence accession numbers are given in parentheses.

\section{DISCUSSION}

The results of the phenotypic and phylogenetic analyses clearly indicate that the novel strains $\left(\mathrm{L} 1-82^{\mathrm{T}}, \mathrm{L} 1-\right.$ 952, L1-8151, L1-81 and L1-93), isolated from human faeces, form a homogeneous group and represent a novel species within the genus Roseburia. These bacteria are Gram-positive, slightly curved rods, nonspore-forming, motile, anaerobic, butyrate-producing and show net utilization of acetate present in the growth medium. They are capable of utilizing a range of carbohydrates and produce several fermentation products, with butyrate and L-lactate identified as the major products.

\section{Differentiation of Roseburia intestinalis sp. nov. from related species}

In view of their phylogenetic and phenotypic similarities and their lack of relatedness to previously described species (Table 3), we propose that the five strains reported here form a novel species, Roseburia intestinalis $\mathrm{sp}$. nov. The most closely related known species are R. cecicola (Stanton \& Savage, 1983a, b; Hespell, 1992), E. rectale, which has been subdivided into five groups based on their ability to ferment different sugars (Moore \& Holdeman Moore, 1986; Andreesen, 1992), and E. oxidoreducens (Krumholz \& Bryant, 1986). However, based on phenotypic properties, $R$. intestinalis is most similar to $E$. rectale subgroup II, while its $16 \mathrm{~S}$ rDNA sequence indicates closest relatedness to $R$. cecicola.

The ability to ferment melezitose has been used to distinguish E. rectale from some other Eubacterium species (Moore \& Holdeman Moore, 1986). Melezitose was not fermented by any of the $R$. intestinalis strains described here, but non-melezitose-fermenting strains of E. rectale have been reported (Moore \& Holdeman Moore, 1986). The former type strain of E. rectale, ATCC 33656, was also reported to ferment inulin, a property shared with strain A1-86 of Barcenilla et al. (2000), shown previously to have $98 \%$ sequence similarity to E. rectale (data not shown). In contrast, inulin was not fermented by $R$. intestinalis. Direct comparison of $R$. intestinalis with representatives of the five $E$. rectale groups and $R$. cecicola could not be undertaken because the $E$. rectale isolates are not extant and $R$. cecicola is unavailable. All strains of $E$. rectale are reported to produce butyrate and lactate, with some acetate, whilst traces of propionate or succinate may be formed. $R$. cecicola is reported to produce only butyrate as a major fermentation product and E. oxidoreducens is reported to produce butyrate and acetate. In contrast, $R$. intestinalis utilizes acetate and produces butyrate, lactate and formate.

Examination of genomic DNA $\mathrm{G}+\mathrm{C}$ content shows that $E$. rectale and $R$. intestinalis have similar genomic

Table 3. Phenotypic properties of $R$. cecicola, $R$. intestinalis, E. rectale and $E$. oxidoreducens

Data for reference taxa were taken from Moore \& Holdeman Moore (1986) (E. rectale), Stanton \& Savage (1983a) (R. cecicola) and Krumholz \& Bryant (1986) (E. oxidoreducens). Cells of all taxa are rods. NR, Not reported.

\begin{tabular}{|c|c|c|c|c|}
\hline Property & $R$. intestinalis & R. cecicola & E. rectale & E. oxidoreducens \\
\hline Cell size $(\mu \mathrm{m})$ & $0.4-0.5 \times 1.0-2.4$ & $0 \cdot 5 \times 2 \cdot 0-5 \cdot 0$ & $0.5-0.6 \times 1.7-4.7$ & $0 \cdot 45 \times 1 \cdot 5-2 \cdot 2$ \\
\hline Gram stain & Variable & Negative & Variable & Positive \\
\hline Flagella & Subterminal & Subterminal & Peritrichous & None \\
\hline Motility & + & + & + & - \\
\hline DNA G $+C$ content $(\mathrm{mol} \%)$ & $29-31$ & $42 \cdot 3$ & 30 & $35 \cdot 7$ \\
\hline Saccharolytic & + & + & + & - \\
\hline \multicolumn{5}{|l|}{ Fermentation of: } \\
\hline Inulin & - & NR & + & - \\
\hline Melezitose & - & NR & $+/-*$ & - \\
\hline Utilization of acetate & + & + & - & - \\
\hline Major fermentation products $\dagger$ & BFL & B & BFLA & $\mathrm{BA}$ \\
\hline
\end{tabular}

* Dependent on subgroup.

$\dagger$ A, Acetate; B, butyrate; F, formate; L, lactate. 
DNA $\mathrm{G}+\mathrm{C}$ contents of between 29 and $31 \mathrm{~mol} \%$, compared with $35.7 \mathrm{~mol} \%$ for E. oxidoreducens (Krumholz \& Bryant, 1986) and $42 \mathrm{~mol} \%$ for $R$. cecicola (Stanton \& Savage, 1983a) (Table 3).

\section{Description of Roseburia intestinalis sp. nov.}

Roseburia intestinalis (in.tes.ti.nal'is. L. gen. n. intestinalis of the intestine, the presumed habitat of the isolates).

Gram-positive to Gram-variable rods, 0.4-0.5 $\times 1 \cdot 0$ $5.0 \mu \mathrm{m}$, with DNA $\mathrm{G}+\mathrm{C}$ content ranging from 29 to $31 \mathrm{~mol} \%$. Motile by means of multiple flagella, subterminally borne. Ferments glucose, arabinose, cellobiose, maltose, fructose, raffinose, sucrose, xylose, xylan and starch. Mannitol, melezitose, rhamnose, ribose, trehalose and inulin are not fermented. Aesculin is hydrolysed and arylamidase activity is not detected. Major fermentation products from glucose and acetate include butyrate, lactate, hydrogen and carbon dioxide. The type strain is strain $\mathrm{L} 1-82^{\mathrm{T}}$ $\left(=\right.$ NCIMB $13810^{\mathrm{T}}=$ DSM $\left.14610^{\mathrm{T}}\right)$.

\section{ACKNOWLEDGEMENTS}

We thank K. Young, C. Nicolle and C. Crost for technical help. The Rowett Research Institute is funded by the Scottish Executive Environment and Rural Affairs Department (SEERAD).

\section{REFERENCES}

Andreesen, J. R. (1992). The genus Eubacterium. In The Prokaryotes, a Handbook on Habitats, Isolation and Identification of Bacteria, 2nd edn, pp. 1914-1924. Edited by M. P. Starr, H. Stolp, H. G. Trüper, A. Balows \& H. G. Schlegel. Berlin: Springer.

Ausubel, F. M., Brent, R., Kingston, R. E., Moore, D. M., Seidman, J. G., Smith, J. A. \& Struhl, K. (editors) (1994). Current Protocols in Molecular Biology, vol. 1, unit 2.4. New York: Wiley.

Barcenilla, A., Pryde, S. E., Martin, J. C., Duncan, S. H., Stewart, C. S., Henderson, C. \& Flint, H. J. (2000). Phylogenetic relationships of butyrate-producing bacteria from the human gut. Appl Environ Microbiol 66, 1654-1661.

Bokkenheuser, V. D., Winter, J., Finegold, S. M., Sutter, V. L., Ritchie, A. E., Moore, W. E. C. \& Holdeman, L. V. (1979). New markers for Eubacterium lentum. Appl Environ Microbiol 37, 1001-1006. Bryant, M. P. (1959). Bacterial species of the rumen. Bacteriol Rev 23, 125-153.

Bryant, M. P. (1972). Commentary on the Hungate technique for culture of anaerobic bacteria. Am J Clin Nutr 25, 1324-1328.

Collins, M. D., Lawson, P. A., Willems, A., Cordoba, J. J., Fernandez-Garayzabal, J., Garcia, P., Cai, J., Hippe, H. \& Farrow, J. A. E. (1994). The phylogeny of the genus Clostridium: proposal for five new genera and eleven new species combinations. Int $J$ Syst Bacteriol 44, 812-826.

Duncan, S. H., Flint, H. J. \& Stewart, C. S. (1998). Inhibitory activity of gut bacteria against Escherichia coli $\mathrm{O} 157$ mediated by dietary plant metabolites. FEMS Microbiol Lett 164, 283-288.

Duncan, S. H., Barcenilla, A., Stewart, C. S., Pryde, S. E. \& Flint, H. J. (2002). Acetate utilization and butyryl CoA: acetate CoA transferase in butyrate-producing bacteria from the human large intestine. Appl Environ Microbiol (in press).

Felsenstein, J. (1989). PHYLIP - phylogeny inference package (version 3.2). Cladistics 5, 164-166.

Franks, A. H., Harmsen, H. J. M., Raangs, G. C., Jansen, G. J., Schut, F. \& Welling, G. W. (1998). Variations of bacterial populations in human feces measured by fluorescent in situ hybridization with group-specific 16S rRNA-targeted oligonucleotide probes. Appl Environ Microbiol 64, 3336-3345.

Gish, W. \& States, D. J. (1993). Identification of protein coding regions by database similarity search. Nat Genet 3, 266-272.

Hespell, R. B. (1992). The genera Butyrivibrio, Lachnospira and Roseburia. In The Prokaryotes, a Handbook on Habitats, Isolation and Identification of Bacteria, 2nd edn, pp. 2022-2033. Edited by M. P. Starr, H. Stolp, H. G. Trüper, A. Balows \& H. G. Schlegel. Berlin: Springer.

Hold, G. L., Smith, E. A., Rappé, M. S. \& 7 other authors (2001). Characterisation of bacterial communities associated with toxic and non-toxic dinoflagellates: Alexandrium spp. and Scrippsiella trochoidea. FEMS Microbiol Ecol 37, 161-173.

Holdeman, L. V., Cato, E. P. \& Moore, W. E. C. (1977). Anaerobe Laboratory Manual, 4th edn. Blacksburg, VA: Virginia Polytechnic Institute and State University.

Holdeman, L. V., Cato, E. P., Burmeister, J. A. \& Moore, W. E. C. (1980). Descriptions of Eubacterium timidum sp. nov., Eubacterium brachy sp. nov., and Eubacterium nodatum sp. nov. isolated from human periodontitis. Int J Syst Bacteriol 30, 163-169.

Johnson, J. L. (1981). Genetic characterization. In Manual of Methods for General Bacteriology, pp. 450-472. Edited by P. Gerhardt, R. G. E. Murray, R. N. Costilow, E. W. Nester, W. A. Wood, N. R. Krieg \& G. B. Phillips. Washington, DC: American Society for Microbiology.

Kimura, M. (1980). A simple method for estimating evolutionary rates of base substitutions through comparative studies of nucleotide sequences. J Mol Evol 16, 111-120.

Krumholz, L. R. \& Bryant, M. P. (1986). Eubacterium oxidoreducens sp. nov. requiring $\mathrm{H}_{2}$ or formate to degrade gallate, pyrogallol, phloroglucinol and quercetin. Arch Microbiol 144, 8-14.

Maidak, B. L., Larsen, N., McCaughey, M. J., Overbeek, R., Olsen, G. J., Fogel, K., Blandy, J. \& Woese, C. R. (1994). The Ribosomal Database Project. Nucleic Acids Res 22, 3485-3487.

Miyazaki, K., Martin, J. C., Marinsek-Logar, R. \& Flint, H. J. (1997). Degradation and utilization of xylans by the rumen anaerobe Prevotella bryantii (formerly P. ruminicola subsp. brevis) $\mathrm{B}_{1} 4$. Anaerobe 3, 373-381.

Moore, W. E. C. \& Holdeman Moore, L. V. (1986). Genus Eubacterium Prévot 1938, 294 ${ }^{\mathrm{AL}}$. In Bergey's Manual of Systematic Bacteriology, vol. 2, pp. 1353-1373. Edited by P. H. A. Sneath, N. S. Mair, M. E. Sharpe \& J. G. Holt. Baltimore: Williams \& Wilkins.

Moore, W. E. C., Moore, L. V. H., Cato, E.P., Wilkins, T. D. \& Kornegay, E. T. (1987). Effect of high-fiber and high-oil diets on the fecal flora of swine. Appl Environ Microbiol 53, 1638-1644.

Mott, G. E. \& Brinkley, A. W. (1979). Plasmenylethanolamine: growth factor for cholesterol-reducing Eubacterium. J Bacteriol 139, 755-760.

Prévot, A. (1966). Manual for the Classification and Determination of the Anaerobic Bacteria (translated by V. Fredette). Philadelphia: Lea and Febiger.

Richardson, A. J., Calder, A. G., Stewart, C. S. \& Smith, A. (1989). Simultaneous determination of volatile and non-volatile acidic fermentation products of anaerobes by capillary gas chromatography. Lett Appl Microbiol 9, 5-8.

Rumney, C. J., Duncan, S. H., Henderson, C. \& Stewart, C. S. (1995). Isolation and characteristics of a wheatbran-degrading butyrivibrio from human faeces. Lett Appl Microbiol 20, 232-236.

Saitou, N. \& Nei, M. (1987). The neighbor-joining method: a new method for reconstructing phylogenetic trees. Mol Biol Evol 4, 406-425.

Sambrook, J., Fritsch, E. F. \& Maniatis, T. (1989). Molecular Cloning: a Laboratory Manual, 2nd edn. Cold Spring Harbor, NY: Cold Spring Harbor Laboratory.

Sans, M. D. \& Crowder, J. G. (1973). Subacute bacterial endocarditis caused by Eubacterium aerofaciens: report of a case. Am J Clin Pathol 59, 576-580.

Scheppach, W., Bartram, H. P. \& Richter, F. (1995). Role of shortchain fatty acids in the prevention of colorectal cancer. Eur $J$ Cancer 31A, 1077-1080. 
Schneider, H. \& Blaut, M. (2000). Anaerobic degradation of flavonoids by Eubacterium ramulus. Arch Microbiol 173, 71-75.

Schneider, H., Simmering, R., Hartmann, L., Pforte, H. \& Blaut, M. (2000). Degradation of quercitin-3-glucoside in gnotobiotic rats associated with human intestinal bacteria. J Appl Microbiol 89, 1027-1037.

Simmering, R., Kleessen, B. \& Blaut, M. (1999). Quantification of the flavonoid-degrading bacterium Eubacterium ramulus in human fecal samples with a species-specific oligonucleotide hybridization probe. Appl Environ Microbiol 65, 3705-3709.

Stanton, T. B. \& Savage, D. C. (1983a). Roseburia cecicola gen. nov., sp. nov., a motile, obligately anaerobic bacterium from a mouse cecum. Int J Syst Bacteriol 33, 618-627.

Stanton, T. B. \& Savage, D. C. (1983b). Colonization of gnotobiotic mice by Roseburia cecicola, a motile, obligately anaerobic bacterium from murine ceca. Appl Environ Microbiol 45, 1677-1684.

Stewart, C. S., Duncan, S. H. \& Flint, H. J. (1990). The properties of forms of Ruminococcus flavefaciens which differ in their ability to degrade cotton cellulose. FEMS Microbiol Lett 72, 47-50.
Suau, A., Bonnet, R., Sutren, M., Godon, J. J., Gibson, G. R., Collins, M. D. \& Doré, J. (1999). Direct analysis of genes encoding $16 \mathrm{~S}$ rRNA from complex communities reveals many novel molecular species within the human gut. Appl Environ Microbiol 65, 4799-4807.

von Engelhardt, W., Bartels, J., Kirschberger, S., Meyer zu Duttingdorf, H. D. \& Busche, R. (1998). Role of short-chain fatty acids in the hind gut. Vet $Q \mathbf{2 0}$ (Suppl. 3), S52-S59.

Weisburg, W. G., Barns, S. M., Pelletier, D. A. \& Lane, D. J. (1991). 16S ribosomal DNA amplification for phylogenetic study. J Bacteriol 173, 697-703.

Willems, A., Amat-Marco, M. \& Collins, M. D. (1996). Phylogenetic analysis of Butyrivibrio strains reveals three distinct groups of species within the Clostridium subphylum of the Gram-positive bacteria. Int $J$ Syst Bacteriol 46, 195-199.

Wood, J., Scott, K. P., Avgustin, G., Newbold, C. J. \& Flint, H. J. (1998). Estimation of the relative abundance of different Bacteroides and Prevotella ribotypes in gut samples by restriction enzyme profiling of PCR-amplified 16S rRNA gene sequences. Appl Environ Microbiol 64, 3683-3689. 